\title{
TAX AVOIDANCE IN V4 COUNTRIES AND SERBIA - INFLUENCE OF COMPANY SIZE ON EFFECTIVE TAX RATE
}

\section{Piotr Luty}

Wroclaw University of Economics and Business, Wroclaw, Poland

\begin{abstract}
:
The article aimed to check company size's impact on the effective tax rate (ETR) in the Visegrad Group countries and Serbia. The research hypothesis suggested a positive relationship between company size and ETR, in line with the political power theory (PPT). This means that greater tax burdens are transferred to larger companies. The research hypothesis was verified with the use of regression models. The results indicate that in Poland, Slovakia, and Hungary, there was a negative correlation between company size and ETR. The conclusions are consistent with the political cost theory (PCT). This may indicate that in developing countries large companies have the tools to lower the tax burden. In 2018 and 2017, there was no statistically significant correlation between the size of the companies and ETR in the Czech Republic and Serbia. Additionally, it was noted that the companies from Hungary and Serbia use IFRS contributed to lowering the ETR.
\end{abstract}

\section{Keywords:}

Visegrad, tax avoidance, effective tax rate.

\section{INTRODUCTION AND HYPOTHESIS DEVELOPMENT}

Paying taxes is inevitable in running a business. From the perspective of the country, it is an essential element in finalizing the state budget. However, tax burden should be correctly calculated not to be an excessive burden for companies and hinder their development. There is often the reluctance to pay taxes in practice, and the problem of tax avoidance has been noticed by many researchers ( Kovermann 2019, Belz, et al. 2019). Based on the review of 79 scientific publications from 20062018 in tax avoidance ( Kovermann 2019), it can be concluded that the research covered companies from highly developed countries in most cases. Based on the analysis of scientific studies (Kovermann 2019 a), it can be concluded that European countries were not at the center of interest in tax avoidance research. Out of 79 quoted studies, only three concerned European countries. It is also noticeable that the conducted research is outdated because, in the cited 79 publications (Kovermann 2019), research samples in most cases ended in 2011. The problem of outdated research results is also confirmed in other publications (Akhtar et al. 2017). Based on the research (Thomsen, Watrin 2018), it is concluded that companies from the United States do not avoid taxes to a greater extent than companies from the 12 largest European countries. The study of these authors was limited by the selection of only the largest European countries. There were no smaller countries in the study,

Correspondence:

Piotr Luty

e-mail:

piotr.luty@ue.wroc.pl including the countries of Central and Eastern Europe.

The hypotheses verification takes place mainly with quantitative variables (Richardson 2007, Akhtar et al. 2019). An in-depth analysis of American companies was also carried out by Dyreng et al. (2017). 
The study results by Dyreng et al. (2017) indicate that international companies did not lower the effective tax rate more than domestic companies.

Many factors contribute to lowering the effective tax rate. It can be concluded that there is no one universal set of factors that would explain the phenomenon of tax avoidance. In different political or economic environments, they will be activated with different intensities of tax avoidance behaviors. The complexity and multifaceted nature of tax avoidance are presented in the research by Badertscher et al. (2013) in terms of the ownership structure's impact. Badertscher et al. (2013) indicate that in companies where the owners influence the company's current affairs, the tax avoidance phenomenon is low. A family business is a particular case of companies in which the ownership and managerial functions are closely related. Mafrolla and D'Amico (2016), Gaaya et al. (2017) come to different conclusions than Badertscher et al. (2013) and indicate that in family companies, there is a greater propensity to avoid taxation.

The analysis of the literature shows the use of various methods of estimating the effective tax rate. The most common methods are using paid corporate income tax (Cash ETR) or tax expense from the profit and loss account ( Kovermann 2019). The use of the tax burden from the profit and loss account is related to accepting high-quality accounting procedures. The financial statements' quality is confirmed by the fact that statutory auditors audit the financial statements. There are studies in bibliography showing the impact of selecting an audit company on tax avoidance. In the studies of Kanagaretnam et al. (2016) and Richardson et al. (2013) and Gaaya al. (2017), it is indicated that the selection of certified auditor from "BIG 4" reduces tax avoidance. Choosing an auditor from "BIG 4" is associated with higher costs of auditing financial statements. The research by Hogan, Noga (2015), or Apostol, Pop (2019) shows a positive relationship between the costs of legal and tax services and tax avoidance.

Due to their function in creating the state budget, tax burdens are controlled by various tax administration bodies. Tax administration bodies introduce various methods of monitoring budget revenues. Kubick et al. (2 016), JiménezAngueira (2018) studied the impact of internal and external monitoring of tax burdens on the phenomenon of tax avoidance.

In the literature, there is often a relationship between tax avoidance and company size. According to the Political Cost Theory (PCT), large companies are more exposed to state action to increase their tax burden. Beltz et al. (2019) indicate that large companies may be subject to additional regulations and that large companies may be forced to undertake increased social responsibility activities. According to PCT, there is a positive relationship between the size of the companies and the ETR.
The second theory describing the relationship between companies' size and the effective tax rate is Political Power Theory (PPT). In line with this theory, it is noted that large companies can influence on political decisions, for example, in the regulation of tax burdens (Beltz et al. (2019)). As a consequence, large companies may present a lower tax burden. The literature also indicates (Beltz et al. (2019)) that the tax burden's sensitivity to political decisions may pertain to selected sectors of economic activity.

Discrepancies in the research results on the effective tax rate indicate the existence of a research gap. The article discusses the impact of the accounting system and companies' size on the number of tax burdens following the PPT. Therefore, a research hypothesis can be made:

H1: There is a positive correlation between ETR and company size.

H2: There is a positive correlation between the use of IFRS and the amount of ETR.

\section{RESEARCH SAMPLE AND METHODOLOGY}

The research sample includes companies from the Visegrad countries (Czech Republic, Poland, Slovakia, Hungary) and Serbia. The choice of the research sample results from the minimal publications on the issue of tax avoidance in Central and Eastern Europe, as well as Serbia. Additionally, the selection of the research sample is influenced by the scope of the IVF grant number 22010083.

The research covers two years: 2017 and 2018. The choice of research periods is based on the availability of financial data, at the time of preparing this paper (September 2020), companies should have approved and published financial statements for 2018. Theoretically, there may still be companies that do not have the approved and published financial statements for 2019 in September 2020. The article presents a pilot study that will be continued in the future.

It will be used in the research on the BvD Orbis database. During the preparation of the research sample, the following search criteria were used:

1. Status - active companies

2. World region / Country / Region in country Czech Republic, Hungary, Poland, Serbia, Slovakia

3. Accounting practice - IFRS, Local GAAP

4. Total assets (m USD) - $\min =0,2018,2017,2016$, 2015,2014 , for all the selected periods, exclusion of companies with no recent financial data and Public authorities / States / Governments

5. Taxation (m USD) - $\min =0,2018,2017,2016$, 2015,2014 , for all the selected periods, exclusion of companies with no recent financial data and Public authorities / States / Governments 
6. $\mathrm{P} / \mathrm{L}$ before tax ( $\mathrm{m}$ USD) $-\min =0,2018,2017$, $2016,2015,2014$, for all the selected periods, exclusion of companies with no recent financial data and Public authorities / States / Governments

7. Size classification - Large, Medium, Very large

Based on the criteria used, companies were active and came from the Visegrad Group countries and Serbia. Additionally, these companies disclosed tax burdens in the profit and loss account, and their total assets were greater than 0 . In the study, the research sample includes medium, large, and very large companies. This assumption stems from the wagered research hypothesis, which will check the relationship between companies' size and the tax burden on the PPT theory. The initial research sample covers 65,376 companies, as shown in Table 1.

Table 1. Initial research sample

\begin{tabular}{|c|c|}
\hline Country & number \\
\hline $\mathrm{CZ}$ & 14452 \\
\hline $\mathrm{HU}$ & 21035 \\
\hline PL & 15292 \\
\hline RS & 5355 \\
\hline SK & 9242 \\
\hline total & 65376 \\
\hline
\end{tabular}

The next stage is the elimination of companies from the financial and banking sector. This sector, due to specific conditions and regulations, may give incomparable results. Companies without being assigned to the economic activity classification were also removed from the database. Table 2 shows the numbers of companies using additional criteria.

Table 2. Research sample - elimination from the financial and banking sector

\begin{tabular}{|c|c|}
\hline Country & number \\
\hline $\mathrm{CZ}$ & 14248 \\
\hline $\mathrm{HU}$ & 20857 \\
\hline PL & 15002 \\
\hline RS & 5334 \\
\hline SK & 9182 \\
\hline Total & 64623 \\
\hline
\end{tabular}

The next stage of database preparation concerned eliminating companies that revealed an effective tax rate of over $100 \%$. Such a situation may result from incorrectly determining deferred income tax or a one-off settlement of assets or provisions for deferred income tax. The final research sample covers 61,219 companies, as shown in Table 3.

Table 3. Final research sample

\begin{tabular}{|c|c|}
\hline Country & number \\
\hline $\mathrm{CZ}$ & 12720 \\
\hline PL & 14608 \\
\hline RS & 5084 \\
\hline SK & 8382 \\
\hline HU & 20425 \\
\hline Total & 61219 \\
\hline
\end{tabular}

Table 4 presents the research sample divided by economic activity sectors, according to the BvD Sector classification.

Table 4. Research sample - sector classification

\begin{tabular}{|c|c|c|c|c|c|c|}
\hline Sector & $\mathrm{CZ}$ & PL & $\mathrm{RS}$ & SK & $\mathrm{HU}$ & Total \\
\hline $\begin{array}{l}\text { Agriculture, } \\
\text { Horticulture \& } \\
\text { Livestock }\end{array}$ & 777 & 114 & 157 & 290 & 805 & 2143 \\
\hline $\begin{array}{l}\text { Biotechnology } \\
\text { and Life } \\
\text { Sciences }\end{array}$ & 49 & 78 & 29 & 16 & 95 & 267 \\
\hline $\begin{array}{l}\text { Business } \\
\text { Services }\end{array}$ & 1407 & 1317 & 472 & 1398 & 2463 & 7057 \\
\hline $\begin{array}{l}\text { Chemicals, } \\
\text { Petroleum, } \\
\text { Rubber \& Plastic }\end{array}$ & 415 & 642 & 178 & 177 & 419 & 1831 \\
\hline Communications & 85 & 74 & 26 & 34 & 109 & 328 \\
\hline $\begin{array}{l}\text { Computer } \\
\text { Hardware }\end{array}$ & 9 & 7 & 34 & 4 & 8 & 62 \\
\hline $\begin{array}{l}\text { Computer } \\
\text { Software }\end{array}$ & 354 & 361 & 89 & 159 & 417 & 1380 \\
\hline Construction & 1201 & 1264 & 410 & 697 & 2292 & 5864 \\
\hline $\begin{array}{l}\text { Food \& Tobacco } \\
\text { Manufacturing }\end{array}$ & 278 & 530 & 326 & 147 & 602 & 1883 \\
\hline $\begin{array}{l}\text { Industrial, Electric } \\
\text { \& Electronic } \\
\text { Machinery }\end{array}$ & 811 & 672 & 188 & 338 & 761 & 2770 \\
\hline $\begin{array}{l}\text { Information } \\
\text { Services }\end{array}$ & 2 & 4 & 2 & 2 & 3 & 13 \\
\hline $\begin{array}{l}\text { Leather, Stone, } \\
\text { Clay \& Glass } \\
\text { products }\end{array}$ & 155 & 220 & 35 & 55 & 159 & 624 \\
\hline $\begin{array}{l}\text { Media \& } \\
\text { Broadcasting }\end{array}$ & thirty & 81 & 18 & 11 & 80 & 220 \\
\hline
\end{tabular}




\begin{tabular}{lcccccc}
\hline $\begin{array}{l}\text { Metals \& Metal } \\
\text { Products }\end{array}$ & 787 & 767 & 206 & 449 & 821 & 3030 \\
\hline $\begin{array}{l}\text { Mining \& } \\
\text { Extraction }\end{array}$ & 43 & 82 & 18 & 22 & 45 & 210 \\
\hline $\begin{array}{l}\text { Miscellaneous } \\
\text { Manufacturing }\end{array}$ & 56 & 40 & 18 & 15 & 43 & 172 \\
\hline $\begin{array}{l}\text { Printing \& } \\
\text { Publishing }\end{array}$ & 79 & 140 & 80 & 50 & 159 & 508 \\
\hline $\begin{array}{l}\text { Property Services } \\
\text { Public }\end{array}$ & 738 & 862 & 39 & 406 & 943 & 2988 \\
\hline $\begin{array}{l}\text { Administration, } \\
\text { Education, Health }\end{array}$ & 187 & 465 & 15 & 136 & 245 & 1048 \\
$\begin{array}{l}\text { Social Services } \\
\text { Retail }\end{array}$ & 461 & 896 & 336 & 883 & 2736 & 5312 \\
\hline $\begin{array}{l}\text { Textiles \& Clothing } \\
\text { Manufacturing }\end{array}$ & 101 & 179 & 153 & 89 & 216 & 738 \\
\hline $\begin{array}{l}\text { Transport } \\
\text { Manufacturing }\end{array}$ & 169 & 152 & 31 & 65 & 96 & 513 \\
\hline $\begin{array}{l}\text { Transport, Freight } \\
\text { \& Storage }\end{array}$ & 610 & 713 & 328 & 497 & 1157 & 3305 \\
\hline $\begin{array}{l}\text { Travel, Personal } \\
\text { \& Leisure }\end{array}$ & 309 & 313 & 142 & 286 & 1091 & 2141 \\
\hline $\begin{array}{l}\text { Utilities } \\
\text { Wotal }\end{array}$ & 416 & 487 & 57 & 125 & 88 & 1173 \\
\hline $\begin{array}{l}\text { Waste Management } \\
\text { Wreatment }\end{array}$ & 158 & 200 & 57 & 63 & 130 & 608 \\
\hline $\begin{array}{l}\text { Wood, Furniture } \\
\text { Manufacturing }\end{array}$ & 234 & 433 & 166 & 159 & 331 & 1323 \\
\hline & 2799 & 3515 & 1474 & 1809 & 4111 & 13708 \\
\hline
\end{tabular}

In order to verify the research hypotheses, the following variables will be used in the study:

- ETR - effective tax rate is based on data from financial statements - profit and loss account. This method of calculating the ETR variable is used when making decisions by companies (Graham et al. (2013), Kraft (2014)), so it will act as an independent variable in the study.

$$
E T R=\frac{\text { income tax }(\text { actual }+ \text { deferred })}{\text { gross profit or loss }}
$$

- LNA - Company size can be measured in many ways. A standard measure of company size applicable to companies listed on regulated capital markets and private companies is a measure based on the size of the balance sheet total (Lazar 2014, Jiménez-Angueira (2018).

$$
L N A=\ln (\text { total assets })
$$

- Accounting practice - a binary variable with a value of 1 for companies using IFRS and a value of 0 for companies applying local GAAP.

The research hypotheses' verification will be carried out using linear regression models for individual countries.

\section{THE RESEARCH RESULTS}

The analysis of the relationship between the companies' size and the ETR will be conducted for each country separately. This is because the analyzed countries had different income tax rates. This is presented in Fig. 1 for 2018 and Fig. 2 for 2017.

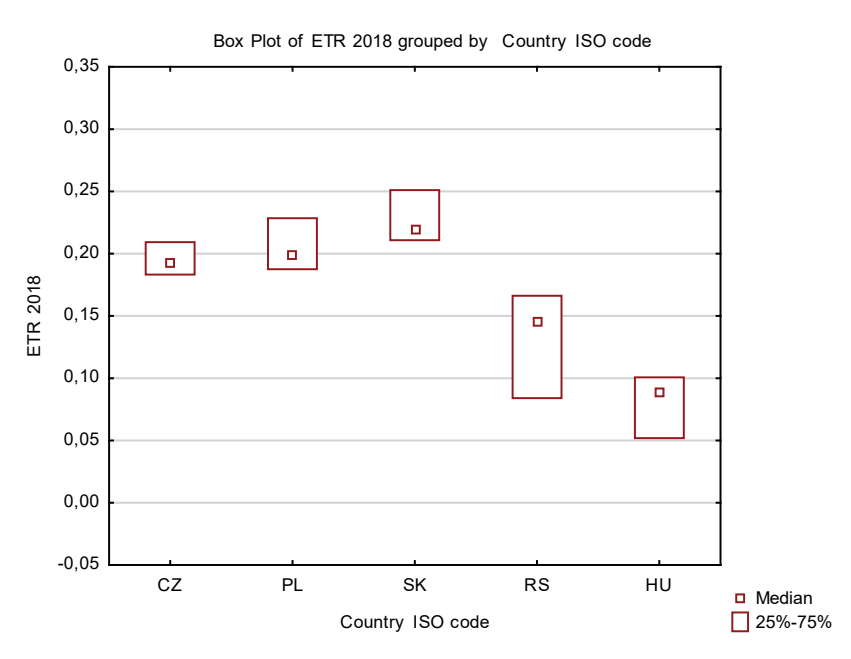

Figure 1. -Effective tax rate in 2018

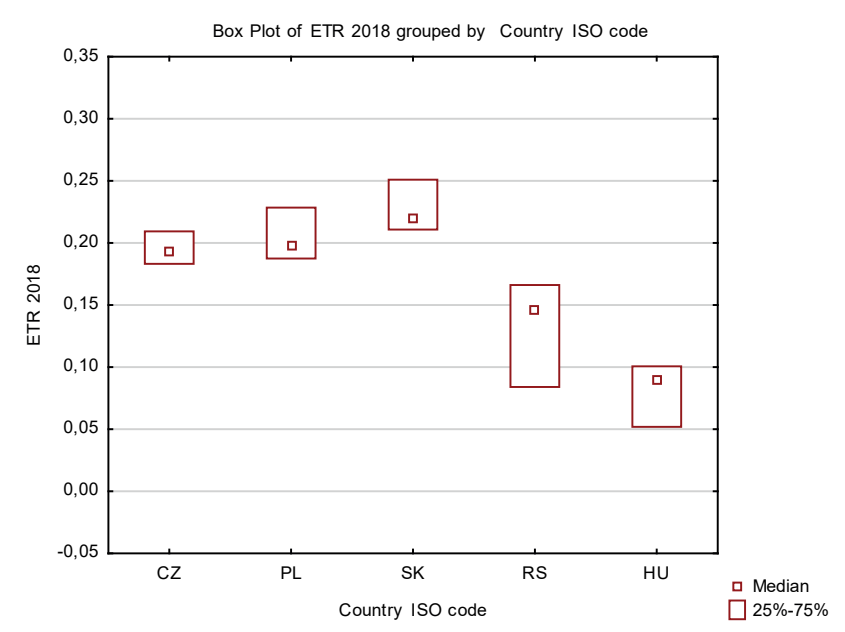

Figure 2. -Effective tax rate in 2017

Based on Figure 1 and Figure 2, it can be seen that in 2018 and 2017, the medians of ETR coincided with the statutory corporate income tax rates. It can, therefore, be concluded that the ETR reflects well the tax burden on companies. 
In line with the research hypotheses, it is expected that the coefficients for the LNA and Accounting practice variables will be positive in the analyzed period of 2018 and 2017. The regression analysis results are presented in Table 5 and Table 6.

Table 5. Regression results for 2018

\begin{tabular}{|c|c|c|c|c|c|}
\hline \multirow[b]{2}{*}{ Effect } & \multicolumn{5}{|c|}{ Aggregate Results Parameter Estimates (date 24.08.2020) Sigma-restricted parameterization } \\
\hline & $\begin{array}{l}\text { Country } \\
\text { ISO code }\end{array}$ & $\begin{array}{l}\text { ETR } 2018 \\
\text { (Param.) }\end{array}$ & $\begin{array}{c}\text { ETR } 2018 \\
\text { (Std.Err) }\end{array}$ & $\begin{array}{c}\text { ETR } 2018 \\
(\mathrm{t})\end{array}$ & $\begin{array}{l}\text { ETR } 2018 \\
\quad(p)\end{array}$ \\
\hline Intercept & $\mathrm{CZ}$ & 0.1824 & 0.0109 & 16.7724 & 0.0000 \\
\hline LNA 2018 & $\mathrm{CZ}$ & 0.0010 & 0.0006 & 1.5518 & 0.1207 \\
\hline $\begin{array}{l}\text { Accounting practice } \\
2018\end{array}$ & $\mathrm{CZ}$ & 0.0089 & 0.0088 & 1.0047 & 0.3151 \\
\hline Intercept & PL & 0.2467 & 0.0067 & 36.6818 & 0.0000 \\
\hline LNA 2018 & $\mathrm{PL}$ & -0.0023 & 0.0006 & -3.5546 & 0.0004 \\
\hline $\begin{array}{l}\text { Accounting practice } \\
2018\end{array}$ & $\mathrm{PL}$ & -0.0047 & 0.0031 & -1.5451 & 0.1223 \\
\hline Intercept & SK & 0.2853 & 0.0152 & 18.7665 & 0.0000 \\
\hline LNA 2018 & SK & -0.0034 & 0.0011 & -3.1557 & 0.0016 \\
\hline $\begin{array}{l}\text { Accounting practice } \\
2018\end{array}$ & SK & -0.0119 & 0.0109 & -1.0943 & 0.2738 \\
\hline Intercept & RS & 0.1711 & 0.0119 & 14.3252 & 0.0000 \\
\hline LNA 2018 & RS & 0.0007 & 0.0012 & 0.6163 & 0.5377 \\
\hline $\begin{array}{l}\text { Accounting practice } \\
2018\end{array}$ & RS & -0.0350 & 0.0071 & -4.8947 & 0.0000 \\
\hline Intercept & $\mathrm{HU}$ & 0.3465 & 0.0244 & 14.2061 & 0.0000 \\
\hline LNA 2018 & $\mathrm{HU}$ & -0.0210 & 0.0007 & -30.8995 & 0.0000 \\
\hline $\begin{array}{l}\text { Accounting practice } \\
2018\end{array}$ & $\mathrm{HU}$ & -0.0781 & 0.0236 & -3.3146 & 0.0009 \\
\hline
\end{tabular}

\begin{tabular}{|c|c|c|c|c|c|c|c|c|c|}
\hline $\begin{array}{l}\text { Dependent } \\
\text { Variable }\end{array}$ & $\begin{array}{l}\text { Country } \\
\text { ISO code }\end{array}$ & $\begin{array}{l}\text { Multiple } \\
\text { (R) }\end{array}$ & $\begin{array}{l}\text { Multiple } \\
\text { (R2) }\end{array}$ & $\begin{array}{l}\text { Adjusted } \\
\text { (R2) }\end{array}$ & $\begin{array}{c}\text { SS } \\
\text { (Model) }\end{array}$ & df (Model) & $\begin{array}{c}\text { MS } \\
\text { (Model) }\end{array}$ & F. & $\mathrm{p}$ \\
\hline ETR 2018 & $\mathrm{CZ}$ & 0.01547 & 0.00024 & 0.00008 & 0.03263 & 2.00000 & 0.01631 & 1.52223 & 0.21827 \\
\hline ETR 2018 & PL & 0.02991 & 0.00089 & 0.00076 & 0.17565 & 2.00000 & 0.08782 & 6.54079 & 0.00145 \\
\hline ETR 2018 & SK & 0.03459 & 0.00120 & 0.00096 & 0.16239 & 2.00000 & 0.08119 & 5.01951 & 0.00663 \\
\hline ETR 2018 & RS & 0.07017 & 0.00492 & 0.00453 & 0.32186 & 2.00000 & 0.16093 & 12.57042 & 0.00000 \\
\hline ETR 2018 & $\mathrm{HU}$ & 0.21155 & 0.04475 & 0.04466 & 16.94004 & 2.00000 & 8.47002 & 478.36311 & 0.00000 \\
\hline
\end{tabular}

Based on Table 5, it can be concluded that in 2018 in 3 countries: Poland, Slovakia, and Hungary, there was a negative correlation between the size of the companies and ETR. This means that larger companies reported lower tax burdens. Additionally, in 2 countries: Serbia and Hungary, the ETR was influenced by the companies' accounting principles - IFRS. 
Table 6. Regression results for 2017

\begin{tabular}{|c|c|c|c|c|c|}
\hline & $\begin{array}{l}\text { Country } \\
\text { ISO code }\end{array}$ & $\begin{array}{c}\text { ETR } 2017 \\
\text { (Param.) }\end{array}$ & $\begin{array}{c}\text { ETR } 2017 \\
\text { (Std.Err) }\end{array}$ & $\begin{array}{c}\text { ETR } 2017 \\
(\mathrm{t})\end{array}$ & $\begin{array}{l}\text { ETR } 2017 \\
\quad(p)\end{array}$ \\
\hline Intercept & $\mathrm{CZ}$ & 0.190864 & 0.010471 & 18.22702 & 0.000000 \\
\hline LNA 2017 & $\mathrm{CZ}$ & 0.000961 & 0.000608 & 1.57967 & 0.114208 \\
\hline $\begin{array}{l}\text { Accounting practice } \\
2017\end{array}$ & $\mathrm{CZ}$ & -0.004098 & 0.008571 & -0.47808 & 0.632599 \\
\hline Intercept & PL & 0.242136 & 0.006463 & 37.46444 & 0.000000 \\
\hline LNA 2017 & PL & -0.002529 & 0.000614 & -4.12210 & 0.000038 \\
\hline $\begin{array}{l}\text { Accounting practice } \\
2017\end{array}$ & PL & 0.000809 & 0.002961 & 0.27329 & 0.784631 \\
\hline Intercept & SK & 0.296460 & 0.014764 & 20.08033 & 0.000000 \\
\hline LNA 2017 & SK & -0.005188 & 0.001012 & -5.12886 & 0.000000 \\
\hline $\begin{array}{l}\text { Accounting practice } \\
2017\end{array}$ & SK & -0.011237 & 0.010764 & -1.04392 & 0.296551 \\
\hline Intercept & RS & 0.190895 & 0.010717 & 17.81292 & 0.000000 \\
\hline LNA 2017 & RS & -0.000517 & 0.001057 & -0.48934 & 0.624619 \\
\hline $\begin{array}{l}\text { Accounting practice } \\
2017\end{array}$ & RS & -0.054669 & 0.006540 & -8.35870 & 0.000000 \\
\hline Intercept & $\mathrm{HU}$ & 0.297205 & 0.022612 & 13.1438 & 0.000000 \\
\hline LNA 2017 & $\mathrm{HU}$ & -0.015821 & 0.000614 & -25.7608 & 0.000000 \\
\hline $\begin{array}{l}\text { Accounting practice } \\
2017\end{array}$ & $\mathrm{HU}$ & -0.073395 & 0.021903 & -3.3509 & 0.000807 \\
\hline
\end{tabular}

\begin{tabular}{lccccccccr}
\hline $\begin{array}{c}\text { Dependent } \\
\text { Variable }\end{array}$ & $\begin{array}{c}\text { Country } \\
\text { ISO code }\end{array}$ & $\begin{array}{c}\text { Multiple } \\
(\mathrm{R})\end{array}$ & $\begin{array}{c}\text { Multiple } \\
(\mathrm{R} 2)\end{array}$ & $\begin{array}{c}\text { Adjusted } \\
(\mathrm{R} 2)\end{array}$ & $\begin{array}{c}\text { SS } \\
(\text { Model })\end{array}$ & df (Model) & $\begin{array}{c}\text { MS } \\
\text { (Model) }\end{array}$ & F. & p \\
\hline ETR 2017 & CZ & 0.015313 & 0.000234 & 0.000077 & 0.030018 & 2 & 0.015009 & 1.490138 & 0.225381 \\
\hline ETR 2017 & PL & 0.035898 & 0.001289 & 0.001152 & 0.236590 & 2 & 0.118295 & 9.422673 & 0.000081 \\
\hline ETR 2017 & SK & 0.056021 & 0.003138 & 0.002900 & 0.409765 & 2 & 0.204883 & 13.18976 & 0.000002 \\
\hline ETR 2017 & RS & 0.116561 & 0.013586 & 0.013198 & 0.737739 & 2 & 0.368869 & 34.99161 & 0.000000 \\
\hline ETR 2017 & HU & 0.177808 & 0.031616 & 0.031521 & 10.19302 & 2 & 5.096509 & 333.3691 & 0.00 \\
\hline
\end{tabular}

Source: own study

The regression analysis in Table 6 shows similar relationships between the variables in 2018 and 2017. In 2017, for three countries: Poland, Slovakia, and Hungary, there was a negative relationship between the size of companies and ETR. In two countries: Serbia and Hungary, the ETR was dependent on the adopted accounting principles. Companies using IFRS had lower ETRs.

\section{CONCLUSION}

The aim of the paper was to check the relationship between the companies' size and the effective tax rate in the Visegrad countries and Serbia. Based on the literature review, it was hypothesized that there is a positive correlation between ETR and the companies' size.
The positive relation indicates that larger companies fulfill their socially responsible role through higher tax burdens. In each country in 2017 and 2018 no relationships confirming the research hypotheses were noticed. In many countries it is noted that the tax base is greater than the gross financial result. The adjustment to the tax expense in the income statement relates to the mandatory recognition of deferred income tax under IFRS. It can, therefore, be concluded that companies applying IFRS should disclose a lower tax burden. This has been confirmed in 2 countries: Serbia and Hungary.

The limitation of the study is the analysis of selected variables influencing ETR. The phenomenon of tax avoidance is very complex, and in further research, it will be developed with further factors influencing the formation of the effective tax rate. 


\section{ACKNOWLEDGMENT}

This paper is part of the project No. 22010083 entitled "Experience sharing of Visegrad countries to tax avoid activity" financed by the International Visegrad Fund.

\section{LITERATURE}

Akhtar, S. (2017). Capital structure of multinational and domestic corporations-a cross-country comparison. Accounting \& Finance, 57(2), 319-349.

Akhtar, S., Akhtar, F., John, K., \& Wong, S. W. (2019). Multinationals' tax evasion: a financial and governance perspective. Journal of Corporate Finance, 57, 35-62.

Apostol, O., \& Pop, A. (2019). 'Paying taxes is losing money': A qualitative study on institutional logics in the tax consultancy field in Romania. Critical Perspectives on Accounting, 58, 1-23.

Belz, T., von Hagen, D., \& Steffens, C. (2019). Taxes and firm size: Political cost or political power?. Journal of Accounting Literature, 42, 1-28.

Dyreng, S. D., Hanlon, M., Maydew, E. L., \& Thornock, J. R. (2017). Changes in corporate effective tax rates over the past 25 years. Journal of Financial Economics, 124(3), 441-463

Gaaya, S., Lakhal, N., \& Lakhal, F. (2017). Does family ownership reduce corporate tax avoidance? The moderating effect of audit quality. Managerial Auditing Journal, 32(7), 731-744.

Graham, J. R., Hanlon, M., Shevlin, T., \& Shroff, N. (2013). Incentives for tax planning and avoidance: Evidence from the field. The Accounting Review, 89(3), 991-1023.

Hogan, B., \& Noga, T. (2015). Auditor-provided tax services and long-term tax avoidance. Review of Accounting and Finance, 14(3), 285-305.
Jiménez-Angueira, C. E. (2018). The effect of the interplay between corporate governance and external monitoring regimes on firms' tax avoidance. Advances in Accounting, 41, 7-24.

Kanagaretnam, K., Lee, J., Lim, C. Y., \& Lobo, G. J. (2016). Relation between auditor quality and tax aggressiveness: Implications of cross-country institutional differences. Auditing: A Journal of Practice \& Theory, 35(4), 105-135.

Kovermann, J., \& Velte, P. (2019). The impact of corporate governance on corporate tax avoidance-A literature review. Journal of International Accounting, Auditing and Taxation, 36, 100270

Kraft, A. (2014). What really affects German firms' effective tax rate?. International Journal of Financial Research, 5(3), 1-19.

Kubick, T. R., Lynch, D. P., Mayberry, M. A., \& Omer, T. C. (2016). The effects of regulatory scrutiny on tax avoidance: An examination of SEC comment letters. The Accounting Review, 91(6), 1751-1780.

Mafrolla, E., \& D'Amico, E. (2016). Tax aggressiveness in family firms and the non-linear entrenchment effect. Journal of family business strategy, 7(3), 178-184.

Richardson, G., \& Lanis, R. (2007). Determinants of the variability in corporate effective tax rates and tax reform: $\mathrm{Ev}$ idence from Australia. Journal of accounting and public policy, 26(6), 689-704.

Richardson, G., Taylor, G., \& Lanis, R. (2013). The impact of board of director oversight characteristics on corporate tax aggressiveness: An empirical analysis. Journal of Accounting and Public Policy, 32(3), 68-88.

Thomsen, M., \& Watrin, C. (2018). Tax avoidance over time: A comparison of European and US firms. Journal of International Accounting, Auditing and Taxation, 33, 40-63. 